\title{
Characteristics of the dairy goat primary sector at the Rio de Janeiro State, Brazil
}

\section{Edizio Santos Junior ${ }^{1}$, Ricardo Augusto Mendonça Vieira ${ }^{2,4}$, Douglas Sampaio Henrique ${ }^{3}$, Alberto Magno Fernandes ${ }^{2}$}

\author{
1 Zootecnista, M.Sc. \\ 2 LZNA/CCTA, Universidade Estadual do Norte Fluminense Darcy Ribeiro. \\ ${ }^{3}$ Departamento de Zootecnia - Universidade Federal de Viçosa. \\ ${ }^{4}$ Bolsista do CNPq.
}

ABSTRACT - A survey was done based on 19 goat shepherds at counties of Centre-highlands, Northern and North-western regions of the Rio de Janeiro State and at the county of Pedra Dourada, Zona da Mata region, State of Minas Gerais. We aimed to characterise the primary sector of the goat milk production chain settled at those regions. Therefore, questionnaires were applied in order to depict profiles of the shepherds, their families, the role of the wife in the activity, the resources available, dependence on income generated by the activity, and how producers administrate their business. Farms were distributed in five strata according to the following daily milk production averages and standard deviations: $8.8 \pm 0.9,15.7 \pm 3.9,22.6 \pm 2.7$, $34.4 \pm 3.4$, and $183.8 \pm 54.2 \mathrm{~L} / \mathrm{d}$. Approximately $42 \%$ of the interviewed producers conducted their activities according to a household production model and the income earned was exclusively from the dairy goat husbandry. Sons and daughters performed an important role in the business $(27.80 \%)$, but most of them $(62.73 \%)$ worked out at non farm activities. The percentage of wives that worked directly in the activity $(\cong 47 \%)$ indicated that it could contribute to gender equity in the rural environment. Most of the production systems (63.16\%) presented positive gross margins. We have noticed, however, that shepherds perceived only the business gross margin and that the most accurate registries taken were those related to revenues. In general, producers of the higher strata were favoured by their larger production scale, but asymptotic behaviours for costs and amounts invested in animals, equipments and buildings were observed. These characteristics should be considered when policies related to the dairy goat primary sector have to be planned.

Key Words: household agriculture, enterprise budget analysis, agribusiness

\section{Características do setor primário da caprinocultura leiteira no estado do Rio de Janeiro, Brasil}

RESUMO - Realizou-se um levantamento com base em 19 caprinoculturas de municípios das regiões Centro-Serrana, Norte e Noroeste do estado do Rio de Janeiro e do município de Pedra Dourada, região da Zona da Mata de Minas Gerais, para caracterizar o setor primário da cadeia produtiva do leite de cabra produzido nestas regiões. Foram aplicados questionários com o objetivo de traçar o perfil dos produtores, de suas famílias, do papel da esposa na atividade, da disponibilidade de recursos, da dependência da renda gerada na atividade e do modo como os produtores administravam seu negócio. As fazendas foram distribuídas em cinco estratos de acordo com as médias de produção diária de leite e os desvios-padrão: 8,8 $\pm 0,9 ; 15,7 \pm 3,9$; $22,6 \pm 2,7 ; 34,4 \pm 3,4 ; 183,8 \pm 54,2 \mathrm{~L} /$ dia. Aproximadamente $42 \%$ dos produtores entrevistados conduziam suas atividades segundo o modelo familiar e obtinham renda exclusivamente da caprinocultura leiteira. Os filhos e as filhas desempenhavam papel importante no negócio $(27,80 \%)$, mas a maior parte $(62,73 \%)$ trabalhava fora, em atividades não-agrícolas. O percentual de esposas que trabalhavam diretamente na atividade $(\cong 47 \%)$ indica sua contribuição para a eqüidade entre os gêneros no meio rural. A maioria dos sistemas de produção $(63,16 \%)$ apresentou margem bruta positiva, todavia, os produtores percebiam apenas a margem bruta do negócio e seus registros mais acurados referiam-se às receitas. Em geral, produtores de estratos mais altos são favorecidos pela produção em escala. Contudo, foram observados comportamentos assintóticos para os custos e montantes investidos em animais, equipamentos e benfeitorias, fato que deve ser considerado no planejamento de políticas relacionadas ao setor primário da caprinocultura leiteira.

Palavras-chave: agricultura familiar, análise econômica, agronegócio

Este artigo foi recebido em 12/2/2007 e aprovado em 17/9/2007.

Correspondências devem ser enviadas para ricardo.vieira@pesquisador.cnpq.br. 


\section{Introduction}

Differently from the goat husbandry practised at the Brazilian Northeast, where goats came into prominence due to its comparable livestock numbers ( $\cong 10^{7}$ heads) in relation to other domestic species, the Brazilian Southeast has only $2.4 \%$ of the goat population in the Country (IBGE, 2004). Nevertheless, the South-eastern region stands out with respect to dairy goat clusters formed that largely participate in the market of fluid goat milk. Another feature about this region is that intensive production systems with specialized dairy breeds predominate (Silva, 1998; Cordeiro, 2001; Borges, 2001). Dairying was an animal characteristic pursued by goat raisers of the South-eastern Brazil as Pinheiro Jr. (1985) had already foreseen in 1940.

The Brazilian and, by extension, the Fluminense societies passed through great modifications during the 171 years since the first registry about dairy goat presence as a farm animal, as we could depict from Pinheiro Jr. (1985). Cabral et al. (2008) pointed out that the average size of the rural properties of the State became shorter throughout the $20^{\text {th }}$ century. They speculated that such contingency could have favoured the development of dairy goat raising into the State, because goats do not demand large investments in herd, building, land, amount of food resources, and allow the employment of all rural family labour force. Another important event mentioned was the consolidation of a stable goat milk commercialization channel to a dairy industry settled at the State that process collected milk by ultra-high temperature, providing a regular long-life milk offer to markets of all Brazilian major cities. In this sense, the characterization of the primary sector of goat milk industry becomes essential to evaluate the present situation of this sector within its productive chain; the information generated could help the establishment of public and private policies aiming to achieve efficiency and positive accounts for dairy goat production systems. Results could help understand how such systems operates, its fitness to the household model, and what are their bottlenecks and problems that, in the long run, could give rise to critical research that will improve sustainability.

\section{Material and Methods}

The primary sector of goat milk industry studied was part of the dairy belt consolidated between the States of Minas Gerais and Rio de Janeiro. Specifically in the latter, the Northern, North-western and Centre-highlands regions shared goat producers whose average daily milk productions ranged from 3 to $300 \mathrm{~L}$. These goat producers were main milk suppliers to the dairy industries settled at the State; some producers used to sell milk in local markets as well. A sample of 19 farmers was taken for a surveying study during 2006. Although the aim of the present study was the primary sector of dairy goat production of the Rio de Janeiro State, dairy goat household producers of the County of Pedra Dourada (MG) were also interviewed because their milk production was delivered to the Associação dos Caprinocultores do Noroeste Fluminense (North-western Fluminense Goat Producers Association), settled in Porciúncula $(\mathrm{RJ})$. It deserves prominence that home consumption of milk was characteristically negligible.

Goat producers were classified according to their average daily milk production by using contingence criteria. Then, questionnaires were applied to characterise them and their dairy goat production systems. Information was gathered to portray the profiles of the farmers in relation to age, schooling, time since became a goat raiser, their residence place, and the structure of their respective families such as schooling and labour force, either or not dedicated to farm and non-farm activities. Other aspects concerning contribution of woman and other family members in the decision-making process of the business and daily tasks performed were asked. Queries were applied concerning available amounts of production factors such as land, building, animals and equipment, as well as amounts of supplies used. Herd variables, by its turn, were estimated based on answers of the farmers concerning herd composition, production and necessary hand labour to perform daily work associated to the activity, either for herd management or business administration. Farmers were asked about information demanded and received from the main supporting services, as well as their interaction with that kind of service and their opinion about the quality of the information received.

Business performances were evaluated by means of the enterprise budget analysis upon information gathered by questionnaires. This allowed the discrimination of revenues, expenses, production factors and produced amounts. Each unit was evaluated on the basis of technical efficiency coefficients. Field data were tabulated on a spreadsheet program (Microsoft ${ }^{\circledR}$ Excel 97) to accomplish financial and economical performance estimates for each farm. Henceforth, total receipts (TR, R \$/year) were calculated from the yearly amount of milk (L) sold times its average price $(\mathrm{R} \$ / \mathrm{L})$, and the quantity of animals ( $\mathrm{kg} /$ year) sold at the local market times the average price of live animals $(\mathrm{R} \$ / \mathrm{kg})$. Herd numbers were assumed stable for all calculations.

Direct expenses done by farmers were computed by estimating the effective operational costs (EOC): wages, 
water, energy, concentrates, minerals, expenses with artificial insemination, hay, fuel, pasture maintenance, buildings and equipment maintenance, medicines, and taxes. Total operational costs (TOC) were estimated by adding EOC to the family labour opportunity cost for daily tasks and/or management, as well as depreciation of building, equipment and animals. The value of management labour was assumed to be $25 \%$ of three Brazilian minimum salaries with all legal taxes and rights included. Depreciation was based on initial and residual values and on useful life of production factors, and it was not applied to land.

Total cost of the activity (TC) was estimated by adding the interest in circulating and fixed capital stocks (including land) to TOC; henceforth, an interest rate of $6 \%$ /year was assumed. The costs of milk production on each enterprise were estimated by discounting revenues provided by selling animals from the TC. All results were divided by the yearly amount of milk sold to estimate the unitary goat milk production costs $(\mathrm{R} \$ / \mathrm{L})$ of the farms surveyed. Gross margins were estimated by the difference between TR and EOC, the net income by the difference between TR and TOC, and profits were estimated by diminishing TC from TR.

Variables were described by means of contingency tables. Whenever appropriate, standard deviations and sample size were indicated and linear correlation coefficients were estimated between described variables and the average daily milk production (ADMP). Correlations were declared significant for $P<0.05$. Variables were plotted against the ADMP as well, and non linear models of asymptotic nature and simple linear regressions were fitted to illustrate variable trends. Coefficients of correlation and probability levels of the tests applied, as well as linear and non linear least squares were accomplished by using SAEG procedures, version 5.0 (1993).

\section{Results and Discussion}

The size of the sample taken formed by dairy goat raisers was $\sum_{\mathrm{i}} \mathrm{n}_{\mathrm{i}}=19$, in which $\mathrm{n}_{\mathrm{i}}$ was the number of producers in each production stratum (i), $\forall \mathrm{i}=1,2, \ldots, 5$. It could be deduced from Table 1 that producers whose production systems constituted the higher stratum $(>100 \mathrm{~L} / \mathrm{d})$ had the highest schooling and were wealthier compared to the others, and that would probably explain why they were prone to run more risks and invested in a larger volume of milk production. On average, it has been 11 years since producers became goat raisers, with the exceptions of strata 10-20 and 20-30 L/d, which were composed by household farmers of the County of Pedra Dourada (MG). These producers were settled a few years ago through a financial government project of land assurance for rural households; otherwise they would not have access to land. Residence at the farm prevailed in all strata $(63.16 \%)$. Residence at the farm facilitates management of the dairy enterprise, because such activity demands the manager presence on a daily basis (Gomes et al., 2003). Some producers lived in urban areas or at rural localities where land was mainly used for amenities, such as at the tourism circuit between the highland Counties of Teresópolis (RJ) and Nova Friburgo (RJ). This condition turned higher the land price and investments in land became more expensive in relation to rural areas. Land has a smaller price at satellite Counties at the Centrenorthern, Northern and North-western regions of the Rio de Janeiro State, favouring policies of land assurance such as those applied at Pedra Dourada (MG).

Wives performed a representative role in business management and/or daily work associated to the dairy goat production, since $47.05 \%$ of them were directly engaged with this activity. Other wives dedicated their time to housework $(17.65 \%)$ or worked out in non-farm activities $(35.30 \%)$. The percentage of wives dedicating time to the activity was an indicative that the dairy goat husbandry could, in fact, promote gender equity amongst the agribusiness context, an environment where the men presence is dominant (Sinn et al., 1999). Beyond a greater efficiency of the woman work in milk processing prior to storage and transportation, women could also contribute by reducing production costs whenever they had a lower scholar background. This aspect was relevant for strata sharing average milk productions lower than $50 \mathrm{~L} / \mathrm{d}$.

The household agriculture model conjugates production factors available to the family, i.e., the labour force and the personal estate. It does not mean, however, that could only be practised in smallholdings. Producers of the higher milk production stratum (>100 L/d, Table 1) were an example, they spent partial or integral time to the activity performing business management and/or aggregating value to the milk by manufacturing sophisticated cheeses seeking specific market niches.

The participation of the family labour in works related to dairy goats was a characteristic of strata until $50 \mathrm{~L} / \mathrm{d}$, because $11.11 \%$ of sons and $16.67 \%$ of daughters older than 12 performed daily tasks associated to the activity. Goats are docile and easy managing animals that demand small amounts of food, low investments in land and building and occupy family labour. This activity deserves mention because it could be implemented in small areas and it could generate enoughincome for the family (Johnson et al., 1986; Cabral et al., 2008). On the other hand, work outside the farm, particularly in non-farm activities, is an actual part of the 
household model, and the importance of this source of income is greater for poorer rural families (Silvestro et al., 2001; Zaibet et al., 2004). Henceforth, the percentage of boys and girls in working age from all strata that worked in non farm activities amounted to $72.22 \%$, what corroborate such hypothesis. Nevertheless, an important part of young farmers, independently of gender, gave assistance to their parents in conducting the dairy goat husbandry. If the family operates the activity profitably the young farmers could succeed their parents on successful business endurance and thus maintaining their rural lives (Silvestro et al., 2001; Zaibet et al., 2004; Cabral et al., 2008).

Results concerning ADMP and respective standard deviations from each stratum were: $8.9 \pm 0.9\left(\mathrm{n}_{1}=2\right)$, $15.7 \pm 3.9\left(\mathrm{n}_{2}=5\right), 22.6 \pm 2.7\left(\mathrm{n}_{3}=2\right), 34.4 \pm 3.4\left(\mathrm{n}_{4}=6\right)$, and $183.8 \pm 54.2\left(\mathrm{n}_{5}=4\right)$. Despite the heterogeneity of variances detected by applying the Bartlett test $(\mathrm{P}<0.01)$ over ADMP $(\mathrm{L} / \mathrm{d})$, the area effectively occupied by goat production systems $\left(\mathrm{S}_{\mathrm{c}}\right.$, ha) increased linearly as a function of ADMP, but the ratio between the forage production area for goats $\left(S_{f}\right.$, ha) to the $S_{c}$ area, i.e. $S_{f}: S_{c}$, was not correlated to the amount of milk produced daily $(\mathrm{r}=-0.09 ; \mathrm{P}=0.36)$, then a constant proportion of land assigned to forage production roughly described its use by producers:

$$
\left\{\begin{array}{l}
\hat{\mathrm{S}}_{\mathrm{c}}=-0.17+0.06 \times \mathrm{ADMP} ; \mathrm{R}^{2}=0.69 ; \mathrm{n}=19 \\
\hat{\mathrm{S}}_{\mathrm{f}}=0.61 \times \hat{\mathrm{S}}_{\mathrm{c}}
\end{array}\right.
$$

Such relationships did not represent an optimised use of the land by producers, but rather, as could be depicted from Table 2, a description of how land and other production factors were used. Elephant grass (Pennisetum sp.) was the most cultivated forage resource, followed by Panicum and Urochloa species. Goat manure was used for fertilising forage fields, thus reducing dependency on chemical fertilisers. Among the equipment available that was used directly at the production systems, only forage cutter and freezer were present in all strata. Milking machines were observed only for high-scale milk productions, with the exception of one producer of the $30-50 \mathrm{~L} / \mathrm{d}$ stratum.

The does to buck ratios that could be deduced from Table 2 were under the threshold recommended of 25:1 (Ribeiro, 1997). Reproductive management adopted was natural mating, and although many producers were affiliated to associations, the bucks were not shared because producers did not use to loan their bucks, nor associations had interest to invest in high quality bucks as well as in reproduction services. For these probable reasons the ratio was lower than the recommended in all strata. Among herd indices, fertility was within the literature range for European breeds in the tropics (Castro, 1987), and produced daily milk averages per doe were low if compared to the productivity range of 1.9 to $4.4 \mathrm{~kg} / \mathrm{d}$ that can be reached in the tropics by European breeds (AFRC, 1997; Knights \& Garcia, 1997; Nsahlai et al., 2004). The proportion of primiparous to total does was not correlated with ADMP $(\mathrm{r}=-0.28 ; \mathrm{P}=0.12)$.

Table 1 - Profiles of the goat raisers families ${ }^{1}$ according to average daily milk production strata

\begin{tabular}{|c|c|c|c|c|c|c|}
\hline \multirow[t]{2}{*}{ Profile } & \multirow[t]{2}{*}{ Unit } & \multicolumn{5}{|c|}{ Production strata $(\mathrm{L} / \mathrm{d})$} \\
\hline & & $<10$ & $10-20$ & $20-30$ & $30-50$ & $>100$ \\
\hline Distribution $^{1}$ & $\%$ & 10.53 & 26.32 & 10.53 & 31.58 & 21.05 \\
\hline Age & Year & 50 & 53 & 50 & 40 & 47 \\
\hline Schooling & Year & 12 & 5 & 7 & 11 & 17 \\
\hline Goat raiser for & Year & 12 & 2 & 2 & 12 & 10 \\
\hline Resides in the farm ${ }^{1}$ & $\%$ & 5.26 & 26.32 & 10.53 & 5.26 & 15.79 \\
\hline Wife's age ${ }^{2}$ & Year & 44 & 52 & 44 & 28 & 42 \\
\hline Wife's schooling & Year & 8 & 5 & 6 & 6 & 16 \\
\hline Wife works with goats ${ }^{2,3}$ & $\%$ & 5.88 & 23.53 & 11.76 & 11.76 & 5.88 \\
\hline Wife manages goat business & $\%$ & 0 & 11.76 & 5.88 & 11.76 & 5.88 \\
\hline Wife works out ${ }^{2,4}$ & $\%$ & 0 & 0 & 0 & 17.65 & 17.65 \\
\hline Number of sons and daughters & $\mathrm{N}$ & 2.0 & 2.0 & 2.5 & 1.7 & 1.8 \\
\hline Sons/daughters age & Year & 19 & 25 & 22 & 15 & 17 \\
\hline Sons/daughters schooling & Year & 10 & 11 & 12 & 9 & 10 \\
\hline Sons works with goats 3,5 & $\%$ & 0 & 2.78 & 2.78 & 5.56 & 0 \\
\hline Daughters works with goats 3,5 & $\%$ & 5.56 & 5.56 & 5.56 & 0.00 & 0 \\
\hline Sons works out ${ }^{4,5}$ & $\%$ & 2.78 & 11.11 & 2.78 & 8.33 & 10.53 \\
\hline Daughters works out ${ }^{4,5}$ & $\%$ & 2.78 & 8.33 & 2.78 & 2.78 & 10.53 \\
\hline
\end{tabular}

${ }^{1}$ Related to 19 producers.

${ }^{2}$ One producer was single and another was a woman, then the total number of wives was 17.

3 Tasks such as milking of does, feeding of herd, cleaning of buildings, milk preparing for transport or processing were included.

${ }^{4}$ Non-farm activities were included.

${ }^{5}$ Percentage in relation to total (36) of sons and daughters of interviewed producers. 
Similarly, fertility $(\mathrm{r}=-0.11 ; \mathrm{P}=0.33)$ and both ADMP per doe $(\mathrm{r}=-0.26 ; \mathrm{P}=0.14)$ and per lactating doe $(\mathrm{r}=-0.12$; $\mathrm{P}=0.32$ ) were independent of ADMP strata. Common use of European breeds in all strata probably reduced the scale effect. Does were milked twice a day by the majority of goat raisers, but only a few adopted technologies for heat induction and artificial insemination. Criteria for first mating of doelings were either described by interviewed shepherds as age and weight. Although growth of this category was not measured, a poor performance of doelings after weaning could retard revenues and increase fixed costs of the activity (Cabral et al., 2008).

The dairy goat systems studied were conducted according to the household model due to the presence of family labour at all, whether or not family labour was employed for both management and/or daily tasks associated to the activity (Table 3 ). The salaried hand labour, however, increased as milk production scale raised whether observed with respect to the hours spent as a ratio of waged to family labour $\left(\hat{\mathrm{h}}_{\mathrm{C}: \mathrm{F}}\right)$ :

$$
\hat{\mathrm{h}}_{\mathrm{C}: \mathrm{F}}=-1.14+0.14 \times \text { ADMP, } \mathrm{R}^{2}=0.84 ; \mathrm{n}=19
$$

The overall labour efficiency estimated as the ratio between the annual amount of days $\times$ man worked and the milk volume was independent of the production scale ( $\mathrm{r}=-0.24 ; \mathrm{P}=0.16)$.

Training hand labour occurred independently of production scale, but according to the policies of the government extension service (EMATER), only producers of lower production scale were assisted. It should be noted that particular consultants assisted producers of the higher production strata (Table 3). Although information is essential today, approximately $36 \%$ of shepherds did not use any

Table 2 - Characteristics of farms and goat herds ${ }^{1}$ presented according to milk production strata

\begin{tabular}{|c|c|c|c|c|c|c|}
\hline \multirow[t]{2}{*}{ Item } & \multirow[t]{2}{*}{ Unit } & \multicolumn{5}{|c|}{ Production strata (L/d) } \\
\hline & & $<10$ & $10-20$ & $20-30$ & $30-50$ & $>100$ \\
\hline Total are $\mathrm{a}^{2}$ & ha & 4.65 & 10.14 & 16.43 & 10.47 & 36.75 \\
\hline Area for goat production ${ }^{2}$ & ha & 0.52 & 3.11 & 1.50 & 1.58 & 11.23 \\
\hline Forage production area ${ }^{2}$ & ha & 0.30 & 2.36 & 1.00 & 0.93 & 6.5 \\
\hline \multicolumn{7}{|l|}{ Forage resources } \\
\hline Urochloa sp. & $\%$ & 5.26 & 21.05 & 0 & 5.26 & 0 \\
\hline Panicum sp. & $\%$ & 5.26 & 5.26 & 5.26 & 10.53 & 5.26 \\
\hline Pennisetum purpureum & $\%$ & 10.53 & 15.79 & 10.53 & 31.58 & 15.79 \\
\hline Others & $\%$ & 5.26 & 10.53 & 5.26 & 5.26 & 5.26 \\
\hline Use of goat manure & $\%$ & 5.26 & 15.79 & 10.53 & 31.58 & 21.06 \\
\hline \multicolumn{7}{|l|}{ Available equipment ${ }^{2}$} \\
\hline Forage cutter & $\%$ & 5.26 & 21.05 & 10.53 & 31.58 & 21.06 \\
\hline Car & $\%$ & 5.26 & 10.53 & 5.26 & 21.05 & 21.06 \\
\hline Motorcycle & $\%$ & 5.26 & 0 & 5.26 & 10.53 & 5.26 \\
\hline Cart & $\%$ & 5.26 & 0 & 5.26 & 26.32 & 10.53 \\
\hline Milking machine & $\%$ & 0 & 0 & 0 & 5.26 & 15.79 \\
\hline Freezer & $\%$ & 10.53 & 10.53 & 10.53 & 26.32 & 15.79 \\
\hline Service animals ${ }^{1}$ & $\%$ & 5.26 & 15.79 & 5.26 & 26.32 & 5.26 \\
\hline \multicolumn{7}{|l|}{ Herd characteristics ${ }^{2}$} \\
\hline Bucks & head & 1.5 & 1.2 & 2.0 & 2.5 & 5.5 \\
\hline Multiparous does & head & 7.0 & 11.2 & 14.0 & 17.5 & 163.0 \\
\hline Primiparous does & head & 4.0 & 4.4 & 5.0 & 7.2 & 46.5 \\
\hline Lactating does & head & 11.0 & 15.0 & 14.5 & 19.7 & 164.3 \\
\hline Fertility & $\%$ & 85.71 & 81.90 & 82.69 & 59.27 & 71.33 \\
\hline Doelings (3-12 months) & head & 4.0 & 8.0 & 8.5 & 8.7 & 50.0 \\
\hline Doelings (0-3 months) & head & 0 & 0.4 & 0 & 8.3 & 51.5 \\
\hline Milk production/doe & $\mathrm{L} / \mathrm{d}$ & 0.9 & 1.2 & 1.4 & 1.5 & 0.9 \\
\hline Milk production/lactating doe & $\mathrm{L} / \mathrm{d}$ & 0.9 & 1.2 & 1.6 & 1.8 & 1.2 \\
\hline Milking of does twice a day ${ }^{1}$ & $\%$ & 5.26 & 26.32 & 10.53 & 26.32 & 21.06 \\
\hline Use of artificial insemination ${ }^{1}$ & $\%$ & 0 & 0 & 0 & 5.26 & 15.79 \\
\hline \multicolumn{7}{|l|}{ About heat induction ${ }^{1}$} \\
\hline Light program & $\%$ & 0 & 10.53 & 5.26 & 5.26 & 5.26 \\
\hline Light program and buck effect & $\%$ & 0 & 0 & 0 & 10.53 & 0 \\
\hline Light program and hormones & $\%$ & 0 & 0 & 0 & 5.26 & 10.53 \\
\hline \multicolumn{7}{|l|}{ Criteria for doelings first mating 1} \\
\hline Age & $\%$ & 0 & 0 & 5.26 & 5.26 & 0 \\
\hline Weight & $\%$ & 5.26 & 15.79 & 5.26 & 10.53 & 0 \\
\hline Age and weight & $\%$ & 5.26 & 10.53 & 0 & 15.79 & 21.06 \\
\hline
\end{tabular}

${ }_{1}^{1}$ Means and percentages related to 19 producers.

${ }^{2}$ Means within each stratum. 
kind of communication media and this proportion belong to categories of lower ADMP. An important part used internet and specialized magazines. A representative proportion ( $\cong 46 \%$ ) of producers dedicated their lives and earned income solely from the dairy goat husbandry. In addition, owners and their families played an important role in business administration, what kept the participation of a salaried manager only in the higher production stratum (Table 3).

Shepherds received information by means of courses promoted by government (EMATER) or private agencies (SENAR/SEBRAE) concerning feeding of animals, herd and business management, herd health and a genetic improvement, presented in a decreasing order. Nevertheless, how to properly compute production costs, milk market, herd feeding, herd health and genetic improvement were considered subjects of major concern but not offered by agencies. By their turn, EMATER and SEBRAE were cited by all strata and SENAR offered courses frequented by shepherds of the strata until $50 \mathrm{~L} / \mathrm{d}$ (Table 4). This does not mean, however, that such agencies effectively reached all dairy goat shepherds.

Interviewed producers from all strata agreed that subjects concerning herd feeding, management, improvement and health, as well as business administration and production costs were interconnected. All of them knew the importance to register expenses, receipts and herd indices but only the minority answered that took appropriate accounts of revenues and expenses. Generally, only revenues were perceived more accurately.

Investments in equipment, building and animals, as revealed by the enterprise budget analysis presented in Table 5, amounted to 2.28904, 2.47041, 2.44787, 4.27927, and 5.21943 R \$ per litre of milk produced assuming stable herd numbers for each stratum. Although land contributed significantly to the amount invested, it was not depreciated in the economical analysis, nor was an interest rate in land capital applied. It is worthy to note that investments were favoured by scale (Figure 1). As daily milk produced increased, increments spent as investments per litre of milk produced in a year-round basis decreased. Such trends illustrate that goat shepherds producing $50 \mathrm{~L} / \mathrm{d}$ would have to invest proportionately the same amount of capital to double production, whereas a producer of thelower stratum would have to triplicate and multiply by five the respective investments in building (Figure 1, Ya) and equipment (Figure 1, Yb) if they want to pass from 10 to $50 \mathrm{~L} / \mathrm{d}$. Since productivity per doe remained the same despite production strata, higher production scale (>100 L/d) means that more animals are necessary to achieve such volumes of milk productions and individual prices ( $\mathrm{R} \$$ animal or $\mathrm{R} \$ / \mathrm{kg}$ of live weight) normally became reduced if large numbers of animals are negotiated (Figure 1, Yc).

Table 3 - Type of labour force, its characteristics in relation to efficiency, training, business administration, and dedication to the dairy goat husbandry, distributed according to milk production strata ${ }^{1}$

\begin{tabular}{|c|c|c|c|c|c|c|}
\hline \multirow[t]{2}{*}{ Item } & \multirow[t]{2}{*}{ Unit } & \multicolumn{5}{|c|}{ Production strata $(\mathrm{L} / \mathrm{d})$} \\
\hline & & $<10$ & $10-20$ & $20-30$ & $30-50$ & $>100$ \\
\hline \multicolumn{7}{|l|}{ Labour force } \\
\hline Family & $\%$ & 10.53 & 26.32 & 10.53 & 31.58 & 21.05 \\
\hline Waged & $\%$ & 0 & 5.26 & 5.26 & 15.79 & 15.79 \\
\hline Waged:Family ${ }^{2}$ & $\mathrm{~h}_{\mathrm{C} \cdot \mathrm{F}}$ & 0.0 & 0.8 & 4.0 & 4.3 & 23.0 \\
\hline Overall labour efficiency ${ }^{3}$ & $\mathrm{dman} / \mathrm{L}$ & 0.02841 & 0.05192 & 0.04503 & 0.04094 & 0.03113 \\
\hline \multicolumn{7}{|l|}{ Hand-labour training } \\
\hline Extension service (EMATER-RIO) & $\%$ & 5.26 & 15.79 & 5.26 & 5.26 & 0 \\
\hline By farmer himself & $\%$ & 0 & 0 & 5.26 & 21.05 & 15.79 \\
\hline Courses and lectures & $\%$ & 10.53 & 15.79 & 5.26 & 21.05 & 0 \\
\hline Technical consultants & $\%$ & 0 & 0 & 0 & 10.53 & 5.26 \\
\hline Communication media used & $\%$ & & & & & \\
\hline Do not use & $\%$ & 10.53 & 21.05 & 5.26 & 0 & 0 \\
\hline Internet & $\%$ & 5.26 & 0 & 5.26 & 15.79 & 21.06 \\
\hline \multicolumn{7}{|l|}{ Business administration } \\
\hline By the owner & $\%$ & 10.53 & 5.26 & 10.53 & 21.06 & 10.53 \\
\hline By the owner and its family & $\%$ & 0 & 21.05 & 0 & 10.53 & 0 \\
\hline By the owner and a manager & $\%$ & 0 & 0 & 0 & 0 & 10.53 \\
\hline Dedication to goat husbandry only & $\%$ & 5.26 & 10.53 & 0 & 21.06 & 5.26 \\
\hline
\end{tabular}

${ }^{1}$ Related to 19 producers.

2 Dimmensionless ratio.

${ }^{3}$ Estimated as the ratio of days $\times$ man worked per milk produced in a year-round basis (dman/L). 
Table 4 - Relevance of information received, subjects most demanded, and interactivity with government and private extension and training services

\begin{tabular}{|c|c|c|c|c|c|c|}
\hline \multirow[t]{2}{*}{ Item } & \multirow[t]{2}{*}{ Unit $^{1}$} & \multicolumn{5}{|c|}{ Production strata (L/d) } \\
\hline & & $<10$ & $10-20$ & $20-30$ & $30-50$ & $>100$ \\
\hline \multicolumn{7}{|c|}{ Information received considered relevant } \\
\hline Herd feeding & $\%$ & 0 & 5.26 & 5.26 & 10.53 & 5.26 \\
\hline Genetic improvement & $\%$ & 0 & 0 & 0 & 10.53 & 0 \\
\hline Health & $\%$ & 0 & 15.79 & 0 & 15.79 & 0 \\
\hline Herd managing & $\%$ & 10.53 & 5.26 & 10.53 & 26.32 & 0 \\
\hline Business management & $\%$ & 0 & 0 & 0 & 15.79 & 10.52 \\
\hline \multicolumn{7}{|l|}{ Demanded information } \\
\hline Milk market & $\%$ & 0 & 5.26 & 0 & 21.05 & 0 \\
\hline Health & $\%$ & 5.26 & 5.26 & 5.26 & 0 & 0 \\
\hline Production costs & $\%$ & 5.26 & 10.53 & 0 & 15.79 & 5.26 \\
\hline Herd feeding & $\%$ & 0 & 0 & 5.26 & 5.26 & 5.26 \\
\hline Genetic improvement & $\%$ & 0 & 5.26 & 0 & 0 & 5.26 \\
\hline Courses offered by SENAR ${ }^{2}$ & $\%$ & 5.26 & 21.05 & 5.26 & 5.26 & 0 \\
\hline Courses offered by EMATER ${ }^{4}$ & $\%$ & 5.26 & 21.05 & 5.26 & 15.79 & 10.53 \\
\hline
\end{tabular}

1 Percentage in relation to 19 producers.

2 Rural training national service (Syndicate).

3 Service for supporting micro and small enterprises (Syndicate).

${ }^{4}$ Government extension services of the States of Minas Gerais and Rio de Janeiro.
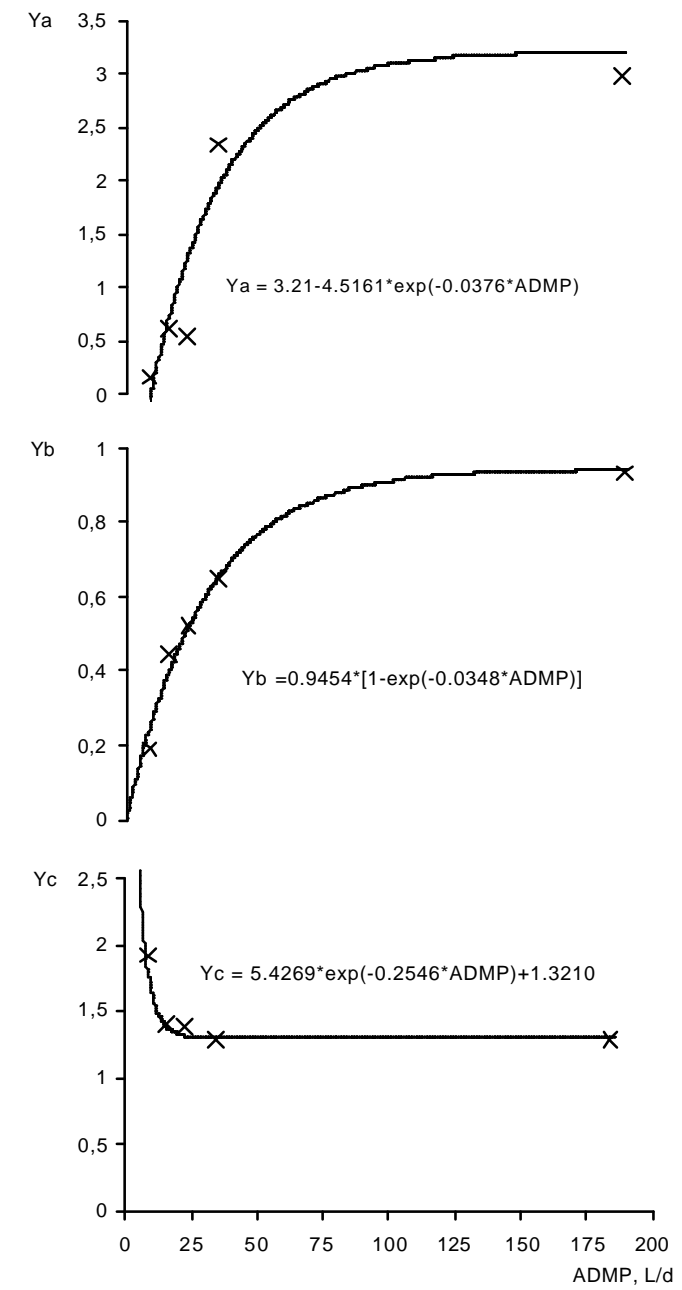

Figure 1 - Trends observed for investments performed $(R \$ / L)$ as functions of the average daily milk production (ADMP, L/d). Ya. building; Yb. equipment; Yc. animals.
Milk and animals sold contributed to 45.35 and $54.65 \%$ of total revenues for farms that produced less than $10 \mathrm{~L} / \mathrm{d}$; the same was not respectively observed for other strata: 84.82 and $15.18 \%$ for $10-20 \mathrm{~L} / \mathrm{d}, 100 \%$ with milk only for 20 $30 \mathrm{~L} / \mathrm{d}, 80.62$ and $19.38 \%$ for $30-50 \mathrm{~L} / \mathrm{d}$, and 83.56 and $16.44 \%$ for farms that produced more than $100 \mathrm{~L} / \mathrm{d}$. The dairy goat reproduction pattern at higher latitudes is seasonal. This characteristic interferes on milk production trends throughout the year (Castro, 1987; Ribeiro, 1990). However, heat induction by technologies such as the light program and the buck associated effect are useful tools for preventing an off season milk shortage, which are accessible to smallholders (Cabral et al., 2008). A seasonal milk production pattern was related to scale because producers from strata until $50 \mathrm{~L} / \mathrm{d}$ concentrated milk production during the season output, i.e., from August to December and in January milk production amounted to $71.50 \%$ of the total produced, whereas $28.50 \%$ of the annual milk produced occurred from February to July. The off seasonal milk produced from production systems of the higher strata (>100 L/d) amounted to $56.03 \%$ of the yearly milk production, and the $43.97 \%$ remaining was produced during season.

According to the linear behaviour described previously, wages increased with production scale and raised the effective operational cost (EOC). The total operational cost (TOC) was affected by the large amounts of investments that had to be depreciated. This accounted for $41.07 \%$ of the total cost (TC) in the lower production stratum. This means 
Table 5 - Budget analyses of goat milk production units ${ }^{1}$ presented in terms of coefficients of technical efficiency distributed according to milk production strata

\begin{tabular}{|c|c|c|c|c|c|}
\hline \multirow[t]{2}{*}{ Item } & \multicolumn{5}{|c|}{ Production strata (L/d) } \\
\hline & $<10$ & $10-20$ & $20-30$ & $30-50$ & $>100$ \\
\hline \multicolumn{6}{|l|}{ 1. Stable capital } \\
\hline Equipment & 0.18912 & 0.44972 & 0.52307 & 0.65222 & 0.93663 \\
\hline Building & 0.16978 & 0.61652 & 0.54427 & 2.33766 & 2.99248 \\
\hline Animals & 1.93014 & 1.40417 & 1.38053 & 1.28939 & 1.29032 \\
\hline Land & 2.35091 & 5.15580 & 1.08642 & 5.32345 & 5.30839 \\
\hline \multicolumn{6}{|l|}{ 2. Revenues } \\
\hline Milk & 0.61329 & 0.93152 & 0.97497 & 1.32472 & 1.15000 \\
\hline Animals & 0.73891 & 0.16666 & 0 & 0.31841 & 0.22630 \\
\hline \multicolumn{6}{|l|}{ 3. Effective operational cost (EOC) } \\
\hline Wages & 0 & 0.18655 & 0.30060 & 0.44619 & 0.50803 \\
\hline Water & 0.04654 & 0 & 0 & 0.01001 & 0 \\
\hline Energy & 0.11873 & 0.05953 & 0.08167 & 0.06207 & 0.09660 \\
\hline Concentrates & 0.69085 & 0.63259 & 0.60451 & 0.42397 & 0.72038 \\
\hline Minerals & 0.03328 & 0.03836 & 0.02051 & 0.02436 & 0.03182 \\
\hline Artificial insemination & 0 & 0 & 0 & 0.00652 & 0.00854 \\
\hline Hay & 0 & 0.01571 & 0 & 0.02592 & 0.04515 \\
\hline Fuel & 0 & 0.03755 & 0.11912 & 0.10745 & 0.06543 \\
\hline Pastures maintenance & 0 & 0.01077 & 0 & 0.00656 & 0.01658 \\
\hline Building maintenance & 0.01672 & 0.01450 & 0 & 0.00999 & 0.04820 \\
\hline Medicines & 0.02871 & 0.01625 & 0.00941 & 0.01401 & 0.03512 \\
\hline Taxes & 0.03511 & 0.00139 & 0.00165 & 0.01094 & 0.12959 \\
\hline \multicolumn{6}{|l|}{ 4. Total operational cost (TOC) } \\
\hline 4.1. EOC & 0.96993 & 1.01319 & 1.13748 & 1.14799 & 1.70546 \\
\hline 4.2. Depreciation & 1.18020 & 0.22234 & 0.22031 & 0.38900 & 0.40165 \\
\hline Equipment & 0.14031 & 0.04047 & 0.04708 & 0.05870 & 0.08430 \\
\hline Building & 0.06250 & 0.05549 & 0.04898 & 0.20933 & 0.19824 \\
\hline Animals & 0.97739 & 0.12637 & 0.12425 & 0.12097 & 0.11911 \\
\hline 4.3. Family labour & 0.35359 & 0.55283 & 0.25398 & 0.18762 & 0.03410 \\
\hline 4.4. Management labour & 0.26519 & 0.24339 & 0.20797 & 0.20761 & 0.06114 \\
\hline \multicolumn{6}{|l|}{ 5. Total cost (TC) } \\
\hline 5.1. TOC & 2.76891 & 2.03175 & 1.81973 & 1.93222 & 2.20235 \\
\hline 5.2. Interest in stable capital & 0.07554 & 0.08152 & 0.08078 & 0.14122 & 0.17224 \\
\hline Equipment & 0.00624 & 0.01484 & 0.01726 & 0.02152 & 0.03091 \\
\hline Building & 0.00560 & 0.02035 & 0.01796 & 0.07714 & 0.09875 \\
\hline Animals & 0.06369 & 0.04634 & 0.04556 & 0.04255 & 0.04258 \\
\hline 5.3. Interest in circulating capital & 0.02910 & 0.03040 & 0.03412 & 0.03444 & 0.05116 \\
\hline 6. Gross margin $(2-3)$ & 0.38227 & 0.08499 & -0.16251 & 0.49515 & -0.32916 \\
\hline 7. Net income $(2-4)$ & -1.41670 & -0.93357 & -0.84477 & -0.28908 & -0.82605 \\
\hline 8. Profit $(2-5)$ & -1.52134 & -1.04549 & -0.95967 & -0.46474 & -1.04945 \\
\hline Goat systems with positive gross margins ${ }^{2}$ & 5.26 & 15.79 & 5.26 & 31.58 & 5.26 \\
\hline Goat systems with positive net income ${ }^{2}$ & 5.26 & 5.26 & 0 & 10.53 & 0 \\
\hline Goat systems with positive profit ${ }^{2}$ & 0 & 0 & 0 & 10.53 & 0 \\
\hline
\end{tabular}

${ }^{1}$ Related to 19 production units.

2 Percentage in each row with respect to all surveyed systems.

that the production factors were more expensive at the smallholding level and public policies should consider this aspect.

The gross margin is the difference between revenues and EOC, the latter being the direct expenses of the goat raiser. Gross margins were negative for the 20-30 L/d and for the higher production strata. The herd stability assumption probably did not hold true because some producers of these strata were retaining replacement doelings to increase herd size, which reduced the selling of animals. The gross margin is an important variable because it reflects short-term results of the enterprise, and producers perceive the business "success" by its evaluation. Goat systems that achieved positive gross margins added up to $63.16 \%$. Other important component is the net income and the scene depicted from Table 5 was not favourable for all strata, at least with the information provided by dairy goat farmers: revenues were not enough to pay off production costs. The net income is the enterprise result in the long run: if negative, the family earnings could be in jeopardy, particularly for producers whose income generation depended solely on activitiesperformed at the 
farm. The endurance of such a scene increases the degree of family poverty and probably leads to its indebtedness, and the owner becomes incapable in maintaining the necessary investments to achieve gains in productivity and scale. This condition culminates with the extinction of the family business, the failure of the hereditary succession of the rural enterprise and leads inexorably to the migration of young farmers to medium and large cities (Silvestro et al., 2001; Zaibet et al., 2004). Fortunately, there were systems that operated with a positive net income $(21.05 \%)$ and even profitably (10.53\%). This is an indicative that the dairy goat husbandry could operate in a positive account perspective if coefficients of technical efficiency that integrate herd productivity, labour and other economic aspects are considered as goals. These goals must be attained for ameliorating performance of the activity and providing income to the owner family competitively whether compared to non farm activities that employhand labour with a lower schooling background.

\section{Conclusion}

Dairy goat husbandry is a consolidated activity at the State of Rio de Janeiro, due to singular characteristics of the milk produced that favour the development of differentiated products. These contributed to consolidating the dairy primary sector and helped to maintain producers at the rural environment.

Most of dairy goat production units probably share positive gross margins, which demonstrate the shortterm viability of the activity. The long-term indicators of the activity, i.e. net income and profitability, however, share negative values in most of them. Clearly, the improvement of efficiency coefficients should be the target to sustain profitability in the long run, but research on this subject is still lacking.

\section{Acknowledgements}

We gratefully acknowledge the assistance of Paulo Roberto Celles Cordeiro (Celles Cordeiro Alimentos Ltda.), André Luis de Almeida Guedes (Queijaria Suíça de Nova Friburgo - FRIALP), Rose and Reinaldo Pires (Cremerie Genéve), and Denilson Bazeth (EMATER-RIO). We are deeply indebted to all Goat Producers for their enthusiastic welcome during interviews. We would like to thank Katia Atoji Henrique for reviews in English. Finally, we wish to thank to CNPq, CAPES, FAPERJ and UENF for grants.

\section{Literature Cited}

AGRICULTURAL AND FOOD RESEARCH COUNCIL - AFRC. The nutrition of goats. Nutrition Abstracts and Reviews Series B, v.67, p.765-830, 1997.

BORGES, C.H.P.; BRESSLAU, S. Custos de Produção do Leite de Cabra - Capril Pedra Branca, Bom Jardim, RJ. In: ENCONTRO DE CAPRINOCULTORES DO SUL DE MINAS E MÉDIA MOGianA, 5., 2001, Espírito Santo do Pinhal. Anais... Espírito Santo do Pinhal: CREUPI, [2001] (CD-ROM).

CABRAL, A.J.; VIEIRA, R.A.M.; SOUZA, P.M. et al. Dairy goat husbandry amongst the household agriculture context: herd indices and economics from a case study in Rio de Janeiro, Brazil. Revista Brasileira de Zootecnia, 2008, submitted for publication.

CASTRO, C.P. Processing of goat milk under less favorable conditions in small rural familiar agroindustry: Present situation and perspectives. In: INTERNATIONAL CONFERENCE ON GOATS, 4., 1987, Brasília. Proceedings... Brasília: IGA/ EMBRAPA, 1987. p.283.

CORDEIRO, P.R.C. Produção de leite de cabra no Brasil. In: REUNIÃO ANNUAL DA SOCIEDADE BRASILEIRA DE ZOOTECNIA, 38., 2001, Piracicaba. Anais... Piracicaba: Sociedade Brasileira de Zootecnia, 2001. p.497.

GOMES, S.T.; LEITE, C.A.M.; COSTA, F.A. Diagnóstico da cadeia produtiva do leite do Estado do Rio de Janeiro. Rio de Janeiro: FAERJ, SEBRAE-RJ, 2003. 262p.

INSTITUTO BRASILEIRO DE GEOGRAFIA E ESTATÍSTICA IBGE [2004]. SIDRA - Banco de dados agregados. Disponível em: <http://www.sidra.ibge.gov.br> Acesso em: 25/10/2004.

JOHNSON, W.L.; VAN EYS, J.E.; FITZHUGH, H.A. Sheep and goats in tropical and subtropical agricultural systems. Journal of Animal Science, v.63, p.1587-1599, 1986.

KNIGHTS, M.; GARCIA, G.W. The status and characteristics of the goat (Capra hircus) and its potential role as a significant milk producer in the tropics: A review. Small Ruminant Research, v.26, p.203-215, 1997.

NICOULIN, M. A gênese de Nova Friburgo - Emigração e colonização suíça no Brasil (1817-1827). Rio de Janeiro: Fundação Biblioteca Nacional, 1995. 367p.

NSAHLAI, I.V.; GOETSCH, A.L.; LUO, J. et al. Metabolizable energy requirements of lactating goats. Small Ruminant Research, v.53, p.253-273, 2004.

PINHEIRO JR., G.C. Caprinos no Brasil. Belo Horizonte: Livraria e Editora Agropecuária, 1985. 177p.

RIBEIRO, S.D.A. Caprinocultura: criação racional de caprinos. São Paulo: Nobel, 1997. 318p.

RIBEIRO, S.D.A.; RIBEIRO, A.C. Passado, presente e futuro da caprinocultura na região sudeste do Brasil. ENCONTRO NACIONAL PARA O DESENVOLVIMENTO DA ESPÉCIE CAPRINA.Anais... Botucatu: Universidade Estadual Paulista, 2004. p.9.

SISTEMA DE ANÁLISES ESTATÍSTICAS E GENÉTICAS - SAEG. Guia do Usuário SAEG Versão 5.0. Viçosa, MG: 1993. 68p.

SILVA, R.R. Agribusiness da Caprinocultura de Leite no Brasil. Salvador: Bureau, 1998. 74p.

SILVESTRO, M.L.; ABRAMOVAY, R.; MELLO, M.A. et al. Os impasses da sucessão hereditária na agricultura familiar. Florianópolis: Epagri; Brasília: Nead/Ministério do Desenvolvimento Agrário, 2001. 120p.

SINN, R.; KETZIS,J.; CHEN,T. The role of woman in the sheep and goat sector. Small Ruminant Research, v.34, p.159$269,1999$.

ZAIBET, L.; DHARMAPALA, P.S.; HOUGHANMI, H.A. et al. Social changes, economic performance and development: the case of goat production in Oman. Small Ruminant Research, v.54, p.131-140, 2004. 